\title{
Effectiveness of Insect Encyclopedia E-Book With Mind Mapping Strategy to Train Students' Creative Thinking Skills
}

\author{
Amin Dwi Cahyanti', Elok Sudibyo ${ }^{2}$, dan Yuni Sri Rahayu ${ }^{3}$ \\ 1,2,3 State University of Surabaya, Surabaya, Indonesia
}

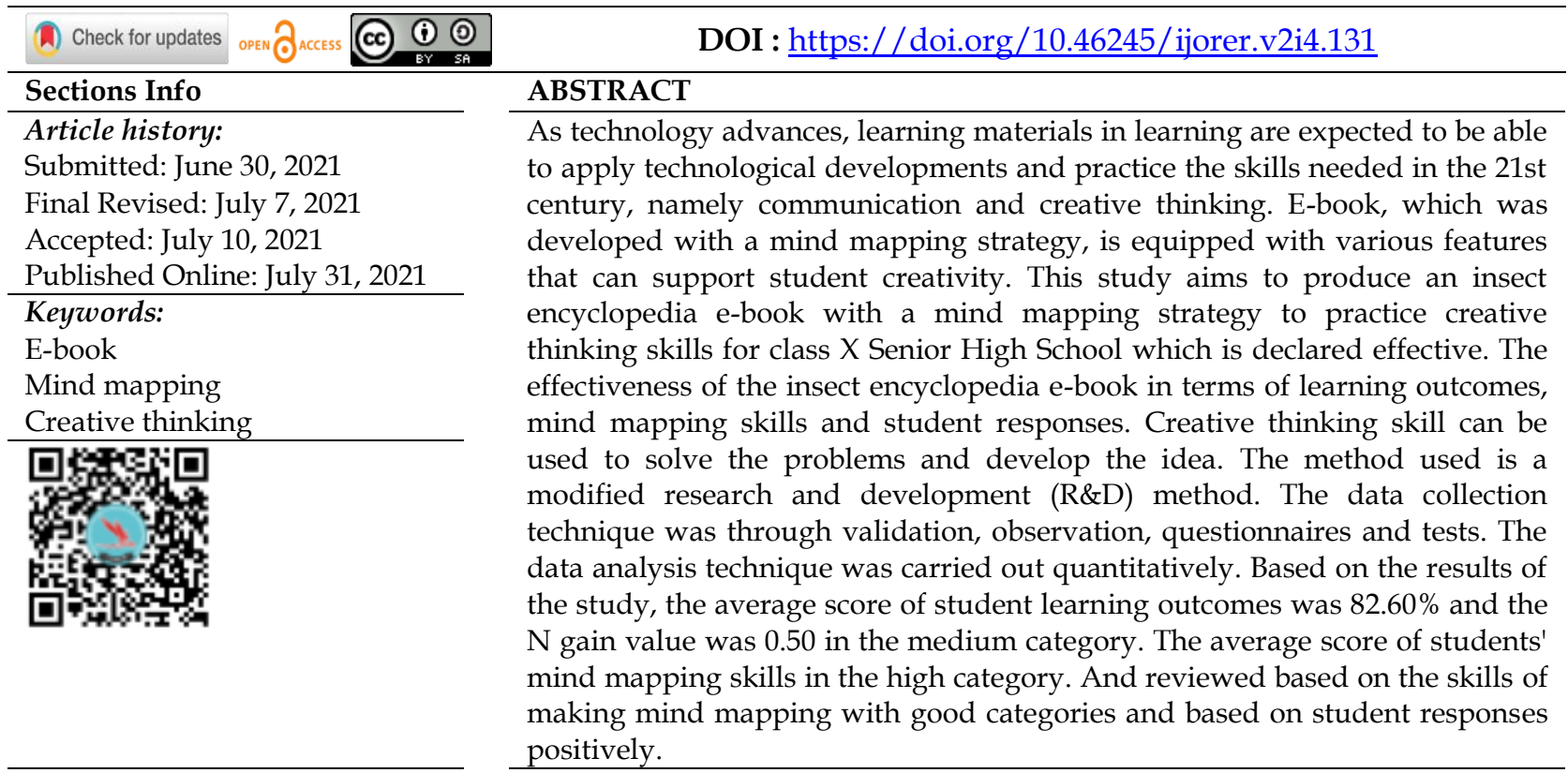

\section{INTRODUCTION}

The rapid development of Science and Technology has an impact on the learning process in the world of education. Nowadays learning is on the current conditions. Technology is the main need of students in the learning process. The use of smartphones properly can improve development in the field of learning (Wu \& Cen, 2017). However, according to research conducted by Jet and Razak (2021) based on their research, many students use smartphones not for studying but for playing social media.

The main learning activity of a student is reading, students' interest in reading can be developed with the guidance of the teacher. Teachers are responsible for building knowledge and instilling experience in the learning process. There are many commercial products that can be used to access information such as books, media, and software. The development of technology that is put to good use can help students access information. Appropriate and appropriate learning media make students more focused, active and independent. Students are more interested in digital book services in the form of e-books compared to printed books (Hidayah et al., 2019). E-books provide easy access for students to get information anytime and anywhere. The learning process carried out using e-books can create an active and motivating learning atmosphere (Fathonah \& Ratnasari, 2021). An active class situation and high motivation by students when studying can facilitate the achievement of learning objectives.

E-books were developed by utilizing the potential of the environment because based on research conducted by Wardhani \& Kerlin (2019) the use of environmental potential 
Effectiveness of Insect Encyclopedia E-Book With Mind Mapping Strategy to Train Students' Creative Thinking Skills

is rarely used when learning takes place. This is because the open environment is far from the reach of schools, requires long hours of lessons so that new innovations are needed to support learning. In biology material, students learn a lot about the diversity of living things, one of the species that is often found with high diversity, and the highest number of species compared to other species is insects. The existence of insects can be used as learning material in animal world material, which is included in the basic competence (KD) grouping animals into phyla based on body layers, body cavity symmetry, and reproduction. This material requires an identification tool that can facilitate students in learning grouping. This identification tool is available in the e-book that will be developed. Wulansari et al (2015) stated that the means of identification with a collection of pictures accompanied by descriptions can help students learn animal material.

The aim of current education according to Hamid (2013) is to improve the quality of human resources by creating creative, highly competitive, and productive human resources. This goal is the reason for the development of Science and Technology which has an impact on increasingly competitive competition. So that skills such as creative thinking, high competitiveness and productivity are needed to face the rapidly changing world. In addition, soft skills such as good character and personality are needed so that every activity can be carried out properly and optimal.

Creative thinking (creativity) is one of the skills that are billed in the 21st century in addition to critical thinking skills (critical thinking), collaboration (collaboration) and communication (communication). Creative thinking needs to be possessed so that students are able to create something new, new ideas, develop, be open, responsive, have creativity, and can contribute to national development (Piirto, 2011). In addition, based on research conducted by Susantini et al (2016) creativity is an important key to success for students to have in facing a changing world.

The e-book developed to train students' creative thinking skills has several features to achieve the desired skills. Besides being equipped with material in the form of text and images that can be enlarged, the e-book is also equipped with several supporting features such as images that can be enlarged as a means of identification, learning video links, article links, mind mapping links to learning materials and analysis questions. In research conducted by Lin (2012) stated that picture books can stimulate students' imagination and creativity, so that this e-book is provided with pictorial features and mind mapping in order to encourage students to be creative and create new ideas.

E-books are arranged with existing features in accordance with the characteristics of the encyclopedia, including alphabetical arrangement following the study of certain sciences, there are pictures and descriptions and are accompanied by an index to make it easier for students to find information. According to Rostikawati and Hari (2019), insect encyclopedias can attract reading interest because the information presented with interesting pictures and can add insight to students.

E-books are integrated with indicators of creative thinking skills including flexibility, fluency, originality and elaboration. Mind mapping that is integrated into the e-book is a new innovation to meet the needs of students and teachers in dealing with school problems technological developments and distribution information so fast. Mind mapping is contrary to traditional information gathering techniques, information is arranged by students according to the workings of the brain. Information that is 
Effectiveness of Insect Encyclopedia E-Book With Mind Mapping Strategy to Train Students' Creative Thinking Skills

arranged in a short, clear and interconnected and artistic nature. Mind mapping is used for taking notes, exchanging ideas, solving problems, learning and memorizing, planning, researching, and elaborating information from various sources.

A similar study was conducted by Adodo (2013) regarding mind mapping, based on the results of his research showing that students who learn to use mind mapping have higher posttest scores than students who study without mind mapping. In research conducted by Caroline et al (2016) also showed that students who studied with the mind mapping strategy had higher posttest scores when compared to students who did not study with the mind mapping strategy and according to him learning with the mind mapping strategy would be more meaningful.

The learning process is carried out in accordance with the learning implementation plan, to determine student learning outcomes and reduce current learning constraints. The existence of an insect encyclopedia e-book with a mind mapping strategy to practice creative thinking skills can provide students with experience. Learning emphasizes e-books with mind mapping strategies to be meaningful so that students can be active, able to develop creativity in thinking. Learning with different strategies allows students to truly learn through experience. At the end of the learning evaluation of learning outcomes is used to determine the achievement of learning objectives with the strategies used and the effectiveness of the learning media.

This study aims to improve students' creative thinking skills through an insect encyclopedia e-book with a mind mapping strategy. Based on the above data found by the researchers, the researchers attempted to conduct research on the development of an insect encyclopedia e-book with a mind mapping strategy to practice the creative thinking skills of $X$ grade high school students.

\section{RESEARCH METHOD General Background}

This research is a development research using the Research and Development (R\&D) model. The stages in this development model consist of potential and problems, gathering information, product design, design validation, design improvement, product testing. Each stage is evaluated and revised. The development of an insect encyclopedia e-book with a mind mapping strategy was carried out at the Postgraduate Program at the State University of Surabaya, this stage was carried out in the odd semester 2020/2021. Phase I, namely the potential and problems, carried out a similar research literature analysis. Phase II is to collect data used by researchers to support the development of an insect encyclopedia e-book with a mind mapping strategy. Phase III product design by designing an insect encyclopedia e-book using the Flip PDF Professional application which produces a draft I which has been reviewed by the examiner during the comprehensive exam. The fourth stage is the validation of the ebook design carried out by a lecturer in the Postgraduate Science department at the State University of Surabaya to produce draft II. Stage V is the revision of the design of the insect encyclopedia e-book according to the suggestions and input of the validator until the actual product is produced. And the last stage, stage VI, is the trial stage for 15 high school students in class $X$. Here are flowchart of research procedure research and development: 


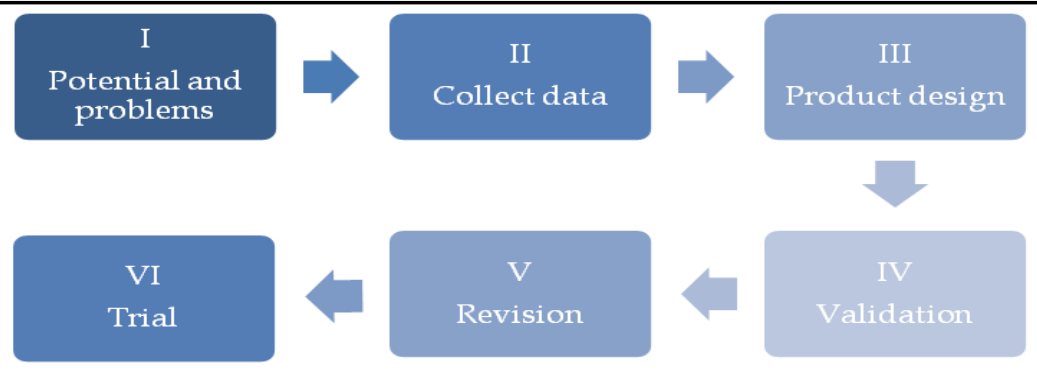

Figure 1. Research procedure.

\section{Sample / Participants / Group}

The research subjects in this study were 15 heterogeneous high school class X students with different academic abilities. The trial of the encyclopedia e-book was conducted online using zoom and google form to determine student learning outcomes for the insect sub-material encyclopedia e-book developed.

\section{Instrument and Procedures}

The data collection method in this research is the questionnaire method and the test method. The questionnaire method was carried out by providing google forms in the form of questions related to the insect encyclopedia e-book. In the google form students answer questions with the choices "Yes" and "No". While the test method is done by giving pretest and posttest questions on google form.

\section{Data Analysis}

The data analysis technique in this research is descriptive quantitative, which describes the research results based on the statistical data obtained. The data is calculated as a percentage of each criterion and all criteria are then interpreted according to the interpretation criteria used and adjusted to the research conducted. The pretest, posttest questions and mind mapping skill test assessed using the scoring method were analyzed based on the following formula:

\section{Score $=$ student's score $/$ maximum score $x 100 \%$}

The pretest and posttest scores were then analyzed to determine the sensitivity of the questions, the following formula was used to determine the sensitivity of the questions:

$$
S=\frac{R A-R B}{T}
$$

S : Question sensitivity

RA : The number of students who answered correctly on posttest

RB : The number of students who answered correctly on pretest

$\mathrm{T}$ : Many students take the exam

The increase in the results of the pretest and posttest were analyzed by the N-Gain formula. 


$$
\left\langle\boldsymbol{g}>=\frac{\%<S f>-\%<S i>}{\%<S \text { maks }>-\%<S i>} \times 100 \%\right.
$$

$\mathrm{S}_{f} \quad=$ Final score $($ posttest)

$S_{i} \quad=$ Initial score (pretest)

$\mathrm{S}_{\text {maks }} \quad=$ maximum possible score.

The equation used to obtain the percentage of student responses is as follows:

$$
P=\frac{\sum \text { student'srespons positive }}{\text { students }} \times 100 \%
$$

$\mathrm{P} \quad=$ Percentage

$\sum \mathrm{K}=$ Total frequency of observation student

$\sum \mathrm{N} \quad=$ Total frequency of observation category

The parameter used to measure the research is the effectiveness of the insect encyclopedia e-book with a mind mapping strategy which is seen based on learning outcomes, mind mapping skills and student responses. The instruments used in this study were Google pre-test and post-test forms, mind mapping assessment rubrics and student response sheets.

\section{RESULTS AND DISCUSSION}

The results of this study resulted in an insect encyclopedia e-book with a Mind Mapping strategy to practice creative thinking skills for class $X$ high school students. Assessment of the effectiveness of the insect encyclopedia e-book can be seen through student learning outcomes and skills in making Mind Mapping.

\section{Learning Outcomes}

Learning outcomes are obtained from the acquisition of students' pretest and posttest scores, the test questions consist of 10 essay questions which are assessed by the scoring method. The following Table shows the scores obtained by 15 students of class X SMA.

Tabel 1. The pretest and posttest scores of 15 students of class $X$.

\begin{tabular}{cccccccc}
\hline Initial Name & $\begin{array}{c}\text { Pretest } \\
\text { Score }\end{array}$ & Criteria & $\begin{array}{c}\text { Posttest } \\
\text { Score }\end{array}$ & Criteria & N-Gain & Category \\
\hline 1 & A & 64 & PG & 74 & G & 0,28 & Low \\
2 & B & 68 & G & 84 & G & 0,50 & Medium \\
3 & C & 69 & G & 87 & VG & 0,59 & Medium \\
4 & D & 67 & PG & 81 & G & 0,42 & Medium \\
5 & E & 76 & G & 86 & VG & 0,83 & High \\
6 & F & 77 & G & 89 & VG & 0,52 & Medium \\
7 & G & 44 & NG & 87 & VG & 0,77 & High \\
8 & H & 52 & PG & 63 & PG & 0,23 & Low \\
9 & I & 56 & PG & 78 & G & 0,50 & Medium \\
10 & J & 63 & PG & 79 & G & 0,43 & Medium \\
11 & K & 64 & PG & 84 & G & 0,56 & Medium \\
12 & L & 74 & G & 87 & VG & 0,50 & Medium
\end{tabular}


Effectiveness of Insect Encyclopedia E-Book With Mind Mapping Strategy to Train Students' Creative Thinking Skills

\begin{tabular}{lccccccc}
\hline Initial Name & $\begin{array}{c}\text { Pretest } \\
\text { Score }\end{array}$ & Criteria & $\begin{array}{c}\text { Posttest } \\
\text { Score }\end{array}$ & Criteria & N-Gain & Category \\
\hline 13 & M & 78 & G & 83 & G & 0,23 & Low \\
14 & N & 83 & G & 90 & VG & 0,54 & Medium \\
15 & O & 72 & G & 87 & VG & 0,56 & Medium \\
\hline \multicolumn{2}{r}{ Average } & $\mathbf{6 7 , 1 3}$ & PG & $\mathbf{8 2 , 6 0}$ & G & $\mathbf{0 , 5 0}$ & Medium \\
\hline
\end{tabular}

The data in Table 1 shows that the average creative thinking skills of 15 class X SMA students for the pretest is 67.13 and the average for the posttest is 82.60 where there is an increase in creative thinking skills after the learning process with the insect encyclopedia e-book is carried out. However, the category of creative thinking skill level of class $X$ students is still classified as moderate. E-books provide various opportunities for students to be creative in their own way. Using e-books in learning helps students to understand by themselves. E-books make it easy to be consumed anywhere, ideal because they can be accessed with cellphones and make it easier for readers to get content that makes it easier for readers to understand the purpose of books because of the varied content (Jet and Razak ,2021). It has also been shown that ebooks with multimedia features such as enlarged images, identification tools, videos, mind mapping, and links that are integrated with creative thinking indicators can help students learn and practice creative thinking skills (Fathonah and Ratnasari, 2021). Data pretest and posttest processed using correlation analyze by SPSS 23. The distribution of data are presentase in Figure 2.

Correlations

\begin{tabular}{|ll|r|r|}
\hline & Pretest & Posttest \\
\hline Pretest & Pearson Correlation & 1 &,$- 251^{\star \pi}$ \\
& Sig. (2-tailed) & &, 000 \\
& N & 351 & 351 \\
\hline Posttest & Pearson Correlation &,$- 251^{\star \star}$ & 1 \\
& Sig. (2-tailed) &, 000 & \\
& N & 351 & 351 \\
\hline \multirow{2}{*}{. Correlation is significant at the 0.01 level (2-tailed). }
\end{tabular}

Figure 2. Correlations analyze.

Figure 2 shows both pretest and posttest results of cognitive students based on correlation analysis between pretest and posttest, it shows that the significance value of 0.000 is less than 0.005 so the pretest and posttest are correlated with each other. Then for the Pearson correlation value of 0.251 , it shows the degree of relationship in a weak correlation with a negative sign indicating the opposite direction. The results of the pretest and posttest that have been carried out by students can be used to determine the sensitivity of the questions that have been developed. The purpose of knowing the sensitivity of this question is to determine the effectiveness of a lesson. The following describes the sensitivity of each item developed according to the indicators of creative thinking in Table 2. 


\begin{tabular}{ccccc}
\hline \multicolumn{5}{c}{ Tabel 2. Question sensitivity. } \\
\hline & $\begin{array}{c}\text { The Correct Pretest } \\
\text { Answer (RB) }\end{array}$ & $\begin{array}{c}\text { Correct Posttest } \\
\text { Answer (RA) }\end{array}$ & Sensitivity & Category \\
\hline 1 & 13 & 10 & $-0,20$ & Less sensitive \\
2 & 5 & 12 & 0,47 & Sensitive \\
3 & 1 & 6 & 0,33 & Sensitive \\
4 & 7 & 14 & 0,47 & Sensitive64 \\
5 & 6 & 11 & 0,53 & Sensitive \\
6 & 4 & 12 & 0,53 & Sensitive \\
7 & 5 & 10 & 0,33 & Sensitive \\
8 & 9 & 11 & $-0,20$ & Less sensitive \\
9 & 5 & 13 & 0,40 & Sensitive \\
10 & 7 & 0,40 & Sensitive \\
& Average item sensitivity & 0,35 & Sensitive \\
\hline
\end{tabular}

Based on the sensitivity analysis of the questions through the students' pretest and posttest results, the average sensitivity score of the questions was 0.35 sensitive categories. The average indicates that the questions that have been prepared are good and suiTable for use. However, there are only 2 questions that have a less sensitive category. In the problem, a graph of the distribution of insects is presented, students are asked to analyze what factors influence it. Difficulty in analyzing can affect the level of success of students in answering questions. Less sensitive questions will be revised so that they are able to adjust to students' abilities.

Each item has indicators of creative thinking skills, including fluency, originality, flexibility, and elaboration. There are 10 essay questions that need to be answered by students, here are the criteria for creative thinking for each question: questions number 1 and 5 have fluency indicators, questions number 2,7,10 have elaboration indicators, questions number 3,8,9 have originality indicators and numbers 4 and 6 have flexibility indicators. In the following, the students' level of completeness and the average level of students' creative thinking in answering the pretest and posttest questions are presented in Table 3.

Tabel 3. The level of completeness of students for each item.

\begin{tabular}{llcc}
\hline & \multirow{2}{*}{ Creativity Indicators } & \multicolumn{2}{c}{ Completeness } \\
\cline { 2 - 4 } & Pros) \\
\hline 1 & Fluency & 85,33 & Posttest \\
2 & Elaboration & 33,33 & 66,67 \\
3 & Originality & 10,00 & 80,00 \\
4 & Flexibility & 46,67 & 40,00 \\
5 & Fluency & 40,00 & 93,33 \\
6 & Flexibility & 26,67 & 73,33 \\
7 & Elaboration & 33,33 & 80,00 \\
8 & Originality & 63,33 & 66,67 \\
9 & Originality & 37,33 & 40,00 \\
10 & Elaboration & 50,00 & 73,33 \\
\hline & Averages & $\mathbf{4 2 , 6 0}$ & 86,67 \\
\hline
\end{tabular}


Based on the data in Table 3, the average of 15 students who answered the pretest questions correctly was $42.60 \%$ in the low category. After the learning process was carried out using the insect encyclopedia e-book with a mind mapping strategy to practice creative thinking skills, it increased to $70.00 \%$ in the medium category. The average change showed an increase after learning with the insect encyclopedia e-book. The low value of the pretest is because students have not studied the insect material in detail, so there is a lack of initial understanding of students to answer the questions given. Some students answered only 1 out of 4 rubrics were answered correctly. However, the accuracy of the answers was an important aspect in the assessment of creative thinking. In the indicator questions number 1 and 8 , the student's score decreased when compared to the other 8 questions which increased. In the first question, students are asked to make identification keys and the second question is to analyze the graph. These results indicate that learning with the insect encyclopedia ebook needs to be perfected and the fluency and originality questions indicators need to be revised to help students improve their abilities.

In the 8 questions, the students' creative thinking indicators have increased. E-books with pictures make it easier for students to identify and understand insect material. As research conducted by Lin (2012), good picture books can bring readers into the story, stimulate deep thinking, and teach children to try hard to do good things so that after learning with e-books students' posttest scores increase. This research adopts a mind mapping strategy, students can see mind mapping on existing e-book links to inspire students to make mind maps. Students' skills in making mind mapping can be seen in Table 4 .

Tabel 4. The mind mapping scores of 15 students of class X.

\begin{tabular}{lcc}
\hline & Intial Name & Mind Mapping Scores \\
\hline 1 & $\mathrm{~A}$ & 75 \\
2 & $\mathrm{~B}$ & 58 \\
3 & $\mathrm{C}$ & 92 \\
4 & $\mathrm{D}$ & 83 \\
5 & $\mathrm{E}$ & 100 \\
6 & $\mathrm{~F}$ & 67 \\
7 & $\mathrm{G}$ & 92 \\
8 & $\mathrm{H}$ & 92 \\
9 & $\mathrm{I}$ & 67 \\
10 & $\mathrm{~J}$ & 75 \\
11 & $\mathrm{~K}$ & 75 \\
12 & $\mathrm{~L}$ & 100 \\
13 & $\mathrm{M}$ & 83 \\
14 & $\mathrm{~N}$ & 75 \\
15 & $\mathrm{O}$ & 58 \\
\hline
\end{tabular}

Based on Table 4 regarding students' creative thinking skills through mind mapping, the average student score is 79 in the high category. Mind mapping scoring technique is done by looking at the scoring rubric based on content (writing), concepts (related), and pictures. This is supported by research conducted by Yunus and Chien (2016) in his research claim that more than half of students $56 \%$ make mind mapping easy to make 
Effectiveness of Insect Encyclopedia E-Book With Mind Mapping Strategy to Train Students' Creative Thinking Skills

and they enjoy the mind mapping process. The high average in making mind mapping shows that after learning with the insect encyclopedia e-book, students have the skills to produce a comprehensive and well-organized mind map as a visual design from the information they understand. Here are some pictures of students' mind mapping in Figure 2.

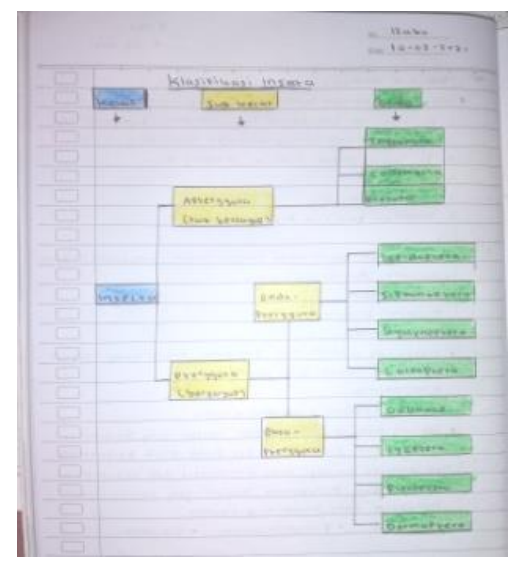

(1)

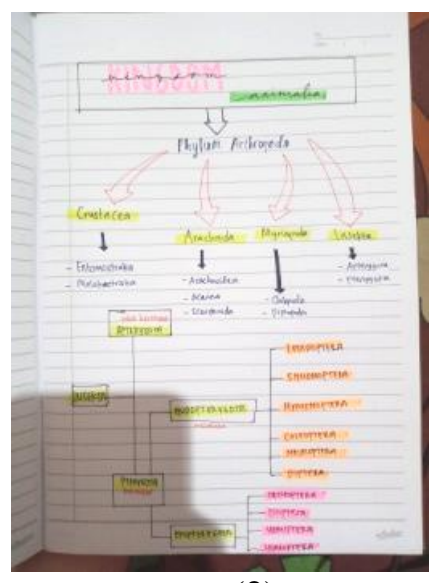

(2)

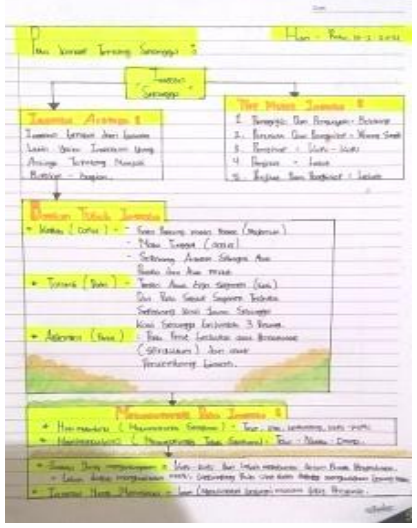

(3)

Figure 2. Student's mind mapping.

Mind mapping helps for problem solving process through visualization and brainstorming provided by pictures and characters using both hands and brain. Thoughts are generated through messages that are attached to concepts and trigger learning motivation and creativity, understanding, and problem solving abilities will increase (Wang et al., 2010).

\section{Student's Responses}

The next indicator of the effectiveness of the insect encyclopedia e-book is student responses. After conducting the pretest and posttest, 15 students of class X SMA who had used the Insect Encyclopedia E-book were asked to fill out a response questionnaire. Student responses were obtained based on a response questionnaire via an online google form. The results of the student response questionnaire analysis after using the insect encyclopedia e-book can be seen in Table 4 as follows:

Tabel 4. Student response recapitulation results.

\begin{tabular}{llrc}
\hline \multicolumn{1}{c}{ Criteria } & \multicolumn{2}{c}{ Persentation (\%) } \\
\cline { 3 - 4 } & \multicolumn{2}{c}{ Yes } & No \\
\hline 1 & $\begin{array}{l}\text { Is the identification of insects presented in the encyclopedia easy } \\
\text { for you to understand? }\end{array}$ & 100 & 0 \\
2 & $\begin{array}{l}\text { Are the insect species in the encyclopedia easy for you to } \\
\text { understand and easy for you to learn? }\end{array}$ & 100 & 0 \\
3 & $\quad$ Can the examples of insects presented in the encyclopedia be \\
& found in the environment? & 100 & 0 \\
4 & Are you interested using encyclopedia in other biology lessons? & 100 & 0 \\
5 & Is the identification activity on the encyclopedia easy to do? & 93,33 & 6,7 \\
6 & Are the pictures in the encyclopedia visible to the eye? & 100 & 0 \\
\hline
\end{tabular}


Effectiveness of Insect Encyclopedia E-Book With Mind Mapping Strategy to Train Students' Creative Thinking Skills

\begin{tabular}{|c|c|c|c|}
\hline & \multirow{2}{*}{ Criteria } & \multicolumn{2}{|c|}{ Persentation (\%) } \\
\hline & & Yes & No \\
\hline 7 & $\begin{array}{l}\text { Does the format exist in helping you to communicate the results } \\
\text { you have obtained in written form? }\end{array}$ & 100 & 0 \\
\hline 8 & $\begin{array}{l}\text { Is the information contained in the encyclopedia in accordance } \\
\text { with the development of science and technology? }\end{array}$ & 100 & 0 \\
\hline 9 & Can you understand the language used in the encyclopedia? & 100 & 0 \\
\hline 10 & $\begin{array}{l}\text { Are the sentences used in the encyclopedia easy for you to } \\
\text { understand? }\end{array}$ & 100 & 0 \\
\hline 11 & $\begin{array}{l}\text { Are the font sizes and shapes used in this encyclopedia accepTable } \\
\text { for you to read? }\end{array}$ & 100 & 0 \\
\hline 12 & Does the cover use attractive colors, images, shapes, and font sizes? & 100 & 0 \\
\hline & Persentation & \multicolumn{2}{|c|}{99,42} \\
\hline & Category & \multicolumn{2}{|c|}{ Very Effective } \\
\hline
\end{tabular}

The average student response score in using the Insect Encyclopedia e-book was 99.42\% with a very effective category. Almost all students answered yes to the Insect Encyclopedia that was developed, ie out of fourteen students got a score of $100 \%$ and one student got a score of $90 \%$. This is because the Insect Encyclopedia e-book is accompanied by pictures, identification tools, videos, articles and mind mapping that clarify the description of insects. According to Fathonah and Ratnasari (2021) the features in the e-book provided and the ease of using e-books help students in learning. In addition, e-books are integrated with creative thinking indicators, namely fluency, flexibility, originality, and elaboration so that students are able to improve creative thinking skills.

The student response questionnaire contains 12 questions, there is 1 question that gets the lowest percentage. The question is about the activity of determining the identification key which gets a percentage of $6.7 \%$ in the answer "No". This is because students are less able to analyze the characteristics of insects and the identification key given is only in the form of terms so it is difficult to understand. However, the encyclopedia e-book provides videos and pictures for insect identification. so students are easy to identify. Besides answering the response questionnaire, students also gave statements about the insect encyclopedia e-book. The statement given by students is that the existence of an insect encyclopedia e-book can make it easier to study insects and can easily identify types of insects. Another statement is that by using the insect encyclopedia e-book, students are more interested in studying the types of insects and students can improve their creative thinking skills with the features in the e-book.

\section{CONCLUSIONS}

Based on the results of research on the development of an insect encyclopedia e-book with a mind mapping strategy that has been carried out, it can be concluded that an insect encyclopedia e-book with a mind mapping strategy to train creative thinking skills of class $X$ high school students is declared effective, reviewed based on learning outcomes with complete criteria and N-gain with medium category. Creative thinking skills of students with an average score of high categories. And reviewed through student responses positively. Insect encyclopedia e-book with a mind mapping strategy 
can train creative thinking skills, creative thinking skill can be used to solve the problems and develop the idea. Limitation in research not all insects used, but only a few insects such as insects of the order Odonata, order Coleoptera, order Diptera, order Hymenoptera, order Lepidoptera, and order Orthoptera. The skills that will be assessed by students in this study are creative thinking skills which include fluency, flexibility (flexibility), originality and elaboration. In future research, the insect encyclopedia ebook can be used for research by training other 21st century skills such as critical thinking, communication skills, and collaborative learning.

\section{ACKNOWLEDGEMENTS}

My gratitude goes to my family who always provide support, my friends in Science Education B class of 2019 Postgraduate, Postgraduate Lecturers at the State University of Surabaya who have provided guidance so that I can complete this research, and Hang Tuah 5 High School Sidoarjo who have provided the opportunity to be able to do this. conduct research.

\section{REFERENCES}

Adodo, S. O. (2013). Effect of mind-mapping as a self-regulated learning strategy on students' achievement in basic science and technology. Mediterranean Journal of Social Sciences, 4(6), 163-172. doi.org/10.5901/mjss.2013.v4n6p163

Caroline, S.A., Yaya, S.K., Sabandar, J., \& Afgan, J.D. (2016). The enhancement of mathematical reasoning ability of junior high school students by applying mind mapping strategy. Journal of Education and Practic, 7(25), 50-58.

Wulansari, D. L., Wisamti, \& Rachmadiarti, F. (2015). Pengembangan atlas keanekaragaman tumbuhan: euphorbiales, myrtales, dan solanales sebagai sarana identifikasi. Bioedu, 4(3), 129-135.

Fathonah, S., \& Ratnasari, E. (2021). Validitas e-book interaktif pada submateri psikotropika untuk melatihkan berpikir kreatif siswa kelas xi SMA. Bioedu, 10(1), 6984.

Hamid, S. (2013). Lecturers' performance and technology at private higher education in south Sulawesi Indonesia. Procedia-Social and Behavioral Sciences, 83(1), 580-584. doi.org/10.1016/j.sbspro.2013.06.110

Hidayah, N., Ramli, M., \& Fauzan, L. (2019). Kemanjuran strategi mind-mapping untuk meningkatkan keterampilan berpikir kreatif dalam pengambilan keputusan karier siswa. Indonesia Journal of Educational Counseling, 3(3), 273-282. doi.org/10.30653/001.201933.109

Wardhani, H. A. K., \& Kerlin. (2019). Identifikasi kupu-kupu di bukit kelampai desa maung dan implementasinya dalam pembuatan e-book. Jurnal Keguruan dan Ilmu Pendidikan, 3(1), 9-15.

Lin, R. (2012). A study of curricullum innovation teaching and creative thingking for picture book creation. Procedia, 2(1), 30-35. doi.org/10.1016/j.ieri.2012.06.047

Piirto, J. (2011). Creativity for 21st century skills. Spinger.

Rostikawati, R. T., \& Susanto, L. H. (2019). Pengembangan ensiklopedia vertebrata untuk meningkatkan pemahaman konsep biologi siswa SMA. Prosiding Seminar Nasional SIMBIOSIS, 4(1), 325-334. 
Effectiveness of Insect Encyclopedia E-Book With Mind Mapping Strategy to Train Students' Creative Thinking Skills

Susantini, E., Isnawati., \& Lisdiana. L. (2016). Effectiveness of genetics student worksheet to improve creative thinking skills of teacher candidate students. Journal of science education, 17(2), 74-79.

Wang, W.C., Lee, C.C., \& Chu, Y.C. (2010). A brief review on developing creative thinking in young children by mind mapping. International Business Research, 3(3), 233-238. doi.org/10.5539/ibr.v3n3p233

$\mathrm{Wu}, \mathrm{T} .$, \& Chen, A. (2017). Combining e-books with mind mapping in a reciprocal teaching strategy for a classical Chinese course. Computers $\mathcal{E}$ Education, 116(1). 10.1016/j.compedu.2017.08.012

Yunus, M., \& Chien, C. H. (2016). The use of mind mapping strategy in malaysian university english test (muet) writing. Creative Education, 7(4), 619-626. doi.org/10.4236/ce.2016.74064

\footnotetext{
*Amin Dwi Cahyanti (Corresponding Author)

Graduate Programs, Science Education,

State University of Surabaya,

Jl. Lidah Wetan, Surabaya, East Java, Indonesia

Email: amin.19010@mhs.unesa.ac.id

Dr. Elok Sudibyo. M.Pd

Graduate Programs, Science Education,

State University of Surabaya,

Jl. Lidah Wetan, Surabaya, East Java, Indonesia

Email: eloksudibyo@unesa.ac.id

Dr.sc.agr.Yuni Sri Rahayu, M.Si

Graduate Programs, Science Education,

State University of Surabaya,

Jl. Lidah Wetan, Surabaya, East Java, Indonesia

Email: yunirahayu@unesa.ac.id
} 